\title{
A Cross-Sectional Survey of Pakistani Muslims Coping with Health Anxiety through Religiosity during the COVID-19 Pandemic
}

\author{
Qaisar Khalid Mahmood ${ }^{1}$ D . Sara Rizvi Jafree ${ }^{2}$. Malik Muhammad Sohail ${ }^{3}$. \\ Muhammad Babar Akram ${ }^{1}$
}

Accepted: 19 February 2021 / Published online: 11 March 2021

(c) The Author(s), under exclusive licence to Springer Science+Business Media, LLC, part of Springer Nature 2021

\begin{abstract}
Investigating the role of religiosity in coping with health anxiety during the outbreak of COVID-19 assumes significance given the continued onslaught of the pandemic and the importance of religion in many societies of the world. The aim of this study is to test the relationship between religious coping and health anxiety in Pakistani Muslims. The online survey method was used to collect data from 408 respondents. Structural equational modeling was performed, with results indicating that people who are suffering with health anxiety opt for religious coping $\left(\beta=.54, R^{2}=.29\right.$, $p<.001)$. We conclude that it is important to consider the role of religion and spirituality during pandemic-induced anxiety. There are implications for counselors, physicians and researchers to integrate religious coping methods when planning mental health interventions during pandemics and otherwise.
\end{abstract}

Keywords COVID-19 $\cdot$ Religiosity $\cdot$ Health anxiety $\cdot$ Coping $\cdot$ Muslims

Qaisar Khalid Mahmood

Qaisar.khalid@iiu.edu.pk

Sara Rizvi Jafree

sarajafree@fccollege.edu.pk

Malik Muhammad Sohail

sohailmujahid@hotmail.com

Muhammad Babar Akram

babar.akram@iiu.edu.pk

1 International Islamic University Islamabad, Room A213, Faculty Block A, Sector H10, Islamabad, Pakistan

2 Forman Christan College University, Lahore, Pakistan

3 Government College University Faisalabad (Chiniot Campus), Chiniot, Pakistan 


\section{Introduction}

After the initial outbreak of the coronavirus in China, the virus spread rapidly around the world, leading to large-scale morbidity and mortality (Zylke et al. 2020). Uncertainty of when the pandemic would end and how it might affect individual lives has led to immeasurable fear and panic across societies (Nicomedes et al. 2020). According to the World Health Organization (2020a), coronavirus has affected more than 107 million people and killed more than 2.4 million people across the world. In Pakistan, the first case of coronavirus was noted on 26th February 2020 (Salman et al. 2020), and one year later in February 2021, government records report that more than 0.5 million people have been diagnosed and 12,000 have succumbed to it. Insecurity about health and indefinite social distancing led to considerable health anxiety in people (Hart 2020). Health anxiety is the excessive fear in individuals with minor or no symptom that they are suffering from a severe or life-threatening medical condition (Asmundson et al. 2020).

Epidemics have been known to create an environment of uncertainty followed by panic, fear and anxiety (Clark 2003; Person et al. 2004). The World Health Organization has recently confirmed that there is high risk of individuals experiencing symptoms of anxiety, psychosis and even suicidal ideation during outbreak of communicable diseases (WHO 2020b). Growing fear of infection and moral distress has been noted in people due to the novelty of the coronavirus (Peteet 2020). Additionally, the lockdown and physical distancing has added to considerable apprehension (VanderWeele 2020). Recent studies confirm that mass quarantine can cause immense fear and anxiety in people (Lima et al. 2020). Researchers have also highlighted that survivors of infectious disease experience psychological problem even after the epidemic is over (James et al. 2019).

Research from previous pandemics like the Ebola virus reveals that survivors experienced different multiple health issues like obsession-compulsion, anxiety and paranoid ideation (Gesser-Edelsburg et al. 2017; Ji et al. 2017; Wadoum et al. 2017). Similarly, the Zika virus pandemic caused considerable anxiety in the public (Blakey et al. 2017). Since the outbreak of the coronavirus pandemic research has confirmed that there is fear in populations across the world with consequences for their mental health (Ahorsu et al. 2020; Fitzpatrick et al. 2020; and Ornell et al. 2020; Lee 2020). Anxiety caused by infectious disease outbreaks is known to lead to behavioral changes in populations (Tan et al. 2004). In the face of social isolation and lockdown, individuals go through complex decisionmaking about how to cope and survive (Abdulkareem et al. 2020). Strategies for coping usually emerge from early socialization (Ruland et al. 2015), ideology and belief systems (Zhao et al. 2015).

In the past few decades, interest in the scientific study of religion and health has risen exponentially (Gall 2000; Hong et al. 2020). Contemporary sociopsychology, including behaviorism, psychodynamics, humanism and transpersonalism, has made efforts to investigate religious coping strategies for healing (Levin 2009). Religious coping comprises cognitive or behavioral coping techniques and often stems directly from an individual's religious beliefs system (Tix et al. 
1998). Religious coping can be an important strategy for populations practicing physical distancing during the coronavirus pandemic. In fact, when people have least control over their lives and face uncertainty, they are known to turn to religion as a coping strategy (Hart et al. 2020). Religious beliefs provide coping responses to stress by facilitating acceptance and adjustment to new life circumstances (Wortmann et al. 2008). Recent studies also suggest that religious and spiritual faith can provide comfort (Levin 2020), emotional stability (Huang et al. 2020) and relief from stress (Chirico et al. 2020).

With a population of 220 million people, Pakistan is the fifth most populated country in the world and the second most populated Muslim country (Worldometer 2020). Religion has a pivotal role in the lives of the $98 \%$ majority Muslim population. People in the country are known to seek guidance from religion whenever they are in trouble and to practice religion as a coping strategy when they face health problems (Shafiq 2020). Psychologists have highlighted a substantial increase in mental health challenges faced by the population since the outbreak of the coronavirus pandemic (Mukhtar 2020). Locally, there has been research about the anxiety experienced by healthcare workers during COVID 19 (Mahmood et al. 2021), stigma faced by family members of COVID-19 patients (Rizvi Jafree et al. 2020) and the socio-psychological experiences of people during the pandemic (Mahmood et al. 2020). However, research about which coping strategies have been used to deal with mental health issues caused by the pandemic has been relatively neglected (Xiang et al. 2020). Furthermore, the role of religious coping strategies to manage pandemic-induced anxiety has been ignored (Lee 2020).

\section{Aim of study}

To the best of the researcher's knowledge, this is the first study attempting to understand the relationship between health anxiety and religious coping during the pandemic in Pakistani Muslims. Understanding the role of religion in coping with the pandemic has implications for planning of policy and resilience in the face of future health crises. Mental health problems caused by this pandemic demand the effort of independent researchers for the planning of policy support and resilience building (Torales et al. 2020).

\section{Methods}

Ethics approval for this study was obtained from the Department of Sociology, International Islamic University, Islamabad. 


\section{Participants}

The survey was administered to the Muslim population of Pakistan above the age of 18 years. Demographic questions related to religious belonging and age were mandatory for submission before the survey could be continued.

\section{Data Collection}

Strict lockdown was initiated by the Government of Pakistan across the country from March 2020 to October 2020 (Saeed et al. 2021). The data for this study were collected between two weeks, from 4th April 2020 to 17th April 2020, while the coronavirus pandemic was at its peak in the country. The online Google survey was used for data collection due to the lockdown and to secure social distancing. An e-link of the study questionnaire was circulated on popular social media platforms, including Facebook, Twitter and Whatsapp. The respondents were requested to participate in the study on a voluntary basis with a written summary of the study objective. Contact details of the first author were shared in case respondents had questions or needed more clarity. Informed consent was taken electronically. A total of 408 respondents completed the questionnaire.

\section{Study Variables}

\section{Socio-demographic Characteristics}

The survey included seven questions related to the socio-demographic characteristics of the respondents, including: gender, education, marital status, perceived social class, family type and district area.

\section{Health Anxiety}

We used the short health anxiety inventory (SHAI) developed by Salkovskis (2002) to measure health anxiety independent of physical health. The instrument demonstrates good reliability, criterion validity and sensitivity to treatment (Abramowitz et al. 2007; Salkovskis et al. 2002). Seven items relevant to the study were used including questions about fear of having a serious illness and constant worry about health (Appendix A). The items were rated on a five-point Likert scale (strongly disagree to strongly agree).

\section{Religious Coping}

The authors reviewed existing scales that measure religiosity in Muslims (Koenig et al. 2010; Koenig et al. 2015; Safari et al. 2017). We used seven items relevant 
to the study, including questions related to offering prayers and reading the Quran during the pandemic, seeking forgiveness from God and the use of rosary beads for regular prayer recitation (Appendix A). The items were rated on a five-point Likert scale (strongly disagree to strongly agree).

\section{Reliability Analysis}

We conducted reliability analysis and found good Cronbach's alpha values for both the health anxiety scale $(\dot{\alpha}=0.867)$ and the religious coping scale $(\alpha=0.893)$.

\section{Data Analysis}

The authors used SPSS 21 to perform statistical analyses. Descriptive statistics were used to report sample characteristics and measures of central tendency (mean and standard deviation). To assess the internal consistency of the scales (health anxiety and religious coping) the Cronbach's alpha coefficient, inter-item correlations, corrected item-total correlations and composite reliability were computed (Appendix A). Last, path analysis and structural equational modeling was performed using AMOS to determine the relationship between health anxiety and religious coping.

\section{Results}

Table 1 presents the socio-demographic characteristics of the sample. Out of the 408 respondents, $244(59.8 \%)$ are female, with $63.0 \%$ residing in urban areas of the country. Majority of the study population represents the middle class of society $(92.4 \%)$. More than half of the respondents are not married (56.9\%) and are living in joint families $(59.8 \%)$.

Inter-item correlations for both variables (health anxiety and religious coping) are significant and range between 0.37 and 0.75 and 0.42 and 0.74 , respectively. Furthermore, corrected item-total correlations for both variables range between 0.56 and 0.74 and 0.56 and 0.75 , respectively. These statistics indicate good internal consistency of both study constructs (Appendix A).

The path analysis results (Table 2) show that fit indices are all within an acceptable limit $\left[\chi^{2} \quad(61, \mathrm{~N}=408)=192.55, p<0.05 ; \mathrm{RMSR}=0.035 ; \mathrm{RMSEA}=0.073\right.$; $\mathrm{GFI}=0.932$; $\mathrm{TLI}=0.941 ; \mathrm{CFI}=0.954]$. For health anxiety, factor loadings were found to be statistically significant ranging from 0.53 to 0.86 . Similarly, factor loadings for religious coping are also significant and within an acceptable range from 0.59 to 0.85 . Health anxiety has a positive relationship (Fig. 1) with 
Table 1 Socio-demographic characteristics of the respondents

\begin{tabular}{lll}
\hline Variables & Frequency & Percentage \\
\hline Gender & 164 & \\
Male & 244 & 40.2 \\
Female & & 59.8 \\
Perceived social class & 17 & \\
Lower class & 377 & 04.2 \\
Middle class & 14 & 92.4 \\
Upper class & & 03.4 \\
Marital status & 232 & \\
Not married & 176 & 56.9 \\
Ever married & & 43.1 \\
Family type & 151 & \\
Nuclear & 244 & 37.0 \\
Joint & 13 & 59.8 \\
Extended & & 03.2 \\
Area of living & 83 & \\
Rural area & 68 & 20.3 \\
Sub urban area & 257 & 16.7 \\
Urban area & & 63.0 \\
Education & 212 & 52.0 \\
Graduation and below & 196 & 48.0 \\
Post-Grnh8aduation & & \\
\hline
\end{tabular}

religious coping $(\beta=0.54, p<0.001)$. The results show that those who are anxious about their health use religion as a coping strategy $\left(R^{2}=0.29, p<0.001\right)$.

\section{Discussion}

Research, prior to COVID-19, confirms that people are at high risk of suffering from anxiety and fear due to infectious disease burdens (Balaratnasingam et al. 2006). Despite this knowledge, mental health problems caused by the coronavirus pandemic are not being addressed adequately by researchers or policy makers (Xiang et al. 2020). There is also concern that pandemic-related anxiety will convert to post-traumatic anxiety in populations across the world even after the coronavirus pandemic is over (Yip et al. 2010). This study attempted to understand the relationship between health anxiety and religious coping in Pakistan, where religion is a strong force in the majority Muslim population (Hassan 1987).

Our findings show that health anxiety has a positive relationship with religious coping, confirming that Muslims in Pakistan who suffer from pandemic-induced anxiety use religiosity as a coping strategy to deal with life circumstances. Past scholars corroborate that religious coping is a salient factor in helping people during health-related crises (Ali et al. 2018; Sohail 2018; Sohail et al. 2019; Zamanian et al. 2015). Local research has also confirmed that youth in Pakistan turn to religion 


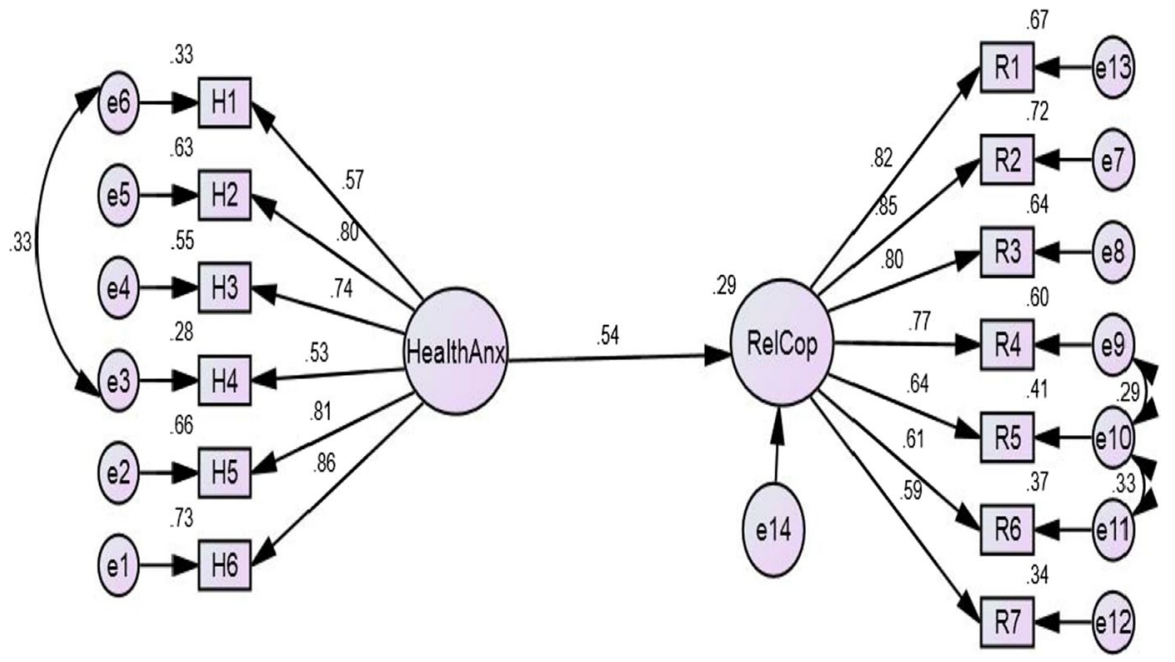

Fig. 1 Path analysis between health anxiety and religious coping

when attempting to cope with the pandemic and altered life circumstances (Salman et al. 2020). Services and support for mental health problems are not favorable in Pakistan (Afridi 2008). Critical shortages or complete absence exists for mental health services within existing health centers across the country (Mukhtar 2020). Moreover, healthcare providers such as psychologists, psychiatrists and counselors are rarely found within the health or education structures of the country (Shah et al. 2019). Neither is there coordination and referral by health social workers for mental health support across the nation (Rizvi Jafree et al. 2020). Inadequate support and coverage for mental health has forced people in the country to find their own solutions for coping with mental health problems (Bashir 2018). Our study implies that religion and spirituality can be used as an integrative tool for improving support and interventions for reducing health anxiety during the pandemic and beyond.

It is important also to take care when using religious coping methods. Valuable research argues that trained providers must simultaneously invest in efforts for promoting religious harmony and peace-building when promoting religious coping methods (Paloutzian et al. 2014). What needs further investigation is the identification of advantages versus disadvantages in dependency on religion as a coping

Table 2 Model fit indices of SEM model

\begin{tabular}{lll}
\hline Psychometric testing & Value & Suggested cutoff \\
\hline$\chi^{2}$ (df) & $192.55(61)^{*}$ & Non-significant \\
Goodness of Fit (GFI) & 0.932 & $\geq 0.90$ \\
Comparative fit index (CFI) & 0.954 & $\geq 0.90$ \\
Tucker-Lewis index (TLI) & 0.941 & $\geq 0.90$ \\
Root mean square error of approxi- & 0.073 & $<0.08$ \\
$\quad$ mation (RMSEA) & & $<0.08$ \\
Root mean square residual (RMSR) & 0.035 & \\
\hline
\end{tabular}


strategy in developing nations like Pakistan (Neuberg et al. 2014). Some developing nations, like Pakistan, have a history of religious extremism, with vulnerable populations at risk of religious fallacies (Javaid 2011). Attention must also be paid to the growth in online religious communities and the type of communication being provided by online religious groups during physical distancing (Campbell 2004).

\section{Limitations}

Limitations of this study include online sampling which might restrict generalizability to populations who do not use or have the internet. In addition, the sample does not represent the illiterate, rural and the lower classes of people in the country. However, our study is important as it contributes to the knowledge about the relationship between health anxiety and religious coping. The study also shows reliability of the instrument, providing impetus for other researchers to repeat the study both in the country and in other nations. Based on the study findings, future research may explore the reasons that build health anxiety in populations and also other religious coping measures that may be adopted in various populations. Finally, we believe our study is an important contribution in mobilizing future longitudinal studies to assess the impact of religious coping in the possible decline of health anxiety.

\section{Conclusion}

Muslims of Pakistan are applying their religious and spiritual faith to cope with health anxiety during the coronavirus pandemic. Policy makers and researchers need to consider factors of religion and spirituality while planning interventions to deal with mental health issues in the face of health and social crises. There is a critical need for healthcare providers, counselors and health social workers to collaborate across different social structures when incorporating religion and spirituality while providing mental health services, during the pandemic and beyond. The prevalence and management of health anxiety in remote and disadvantaged populations who cannot access mental healthcare services must also be considered. Lastly, there is a need for the monitoring of illegitimate or extremist religious leaders and groups affecting vulnerable and illiterate people opting for religious coping in face of health anxiety.

\section{Appendix A}

Items of Health Anxiety Scale.

\begin{tabular}{ll}
\hline H1 & Think I have serious illness \\
H2 & Hear about illness and think I have it \\
\hline H3 & Picturing self-being ill
\end{tabular}


$\mathrm{H} 4$

H5

H6

$\mathrm{H} 7$
Feeling at risk for developing illness

Fear of having serious illness

Worry about health

Family/friends say I worry about my health

Psychometric properties of health anxiety scale.

\begin{tabular}{|c|c|c|c|c|c|c|c|c|c|}
\hline & M & SD & H1 & $\mathrm{H} 2$ & $\mathrm{H} 3$ & $\mathrm{H} 4$ & H5 & H6 & $\begin{array}{l}\text { Corrected Item- } \\
\text { Total Correla- } \\
\text { tion }\end{array}$ \\
\hline H1 & 3.30 & 1.101 & 1 & $0.49^{* *}$ & $0.52^{* *}$ & $0.53^{* *}$ & $0.38^{* *}$ & $0.47^{* *}$ & 0.603 \\
\hline $\mathrm{H} 2$ & 2.01 & 0.921 & & 1 & $0.64^{* *}$ & $0.37^{* *}$ & $0.64^{* *}$ & $0.65^{* *}$ & 0.718 \\
\hline H3 & 2.52 & 1.150 & & & 1 & $0.48^{* *}$ & $0.55^{* *}$ & $0.59^{* *}$ & 0.715 \\
\hline $\mathrm{H} 4$ & 3.45 & 1.110 & & & & 1 & $0.37^{* *}$ & $0.47^{* *}$ & 0.561 \\
\hline H5 & 2.02 & 0.942 & & & & & 1 & $0.75^{* *}$ & 0.687 \\
\hline H6 & 2.31 & 1.128 & & & & & & 1 & 0.749 \\
\hline \multicolumn{9}{|c|}{ Cronbach's alpha ó } & 0.867 \\
\hline \multicolumn{9}{|c|}{ Composite Reliability (CR) } & 0.869 \\
\hline \multicolumn{9}{|c|}{ Average Variance Extracted (AVE) } & 0.532 \\
\hline
\end{tabular}

\section{Items of Religious Coping Scale.}

\begin{tabular}{ll}
\hline R1 & I regularly offer my prayers during COVID-19 pandemic, \\
R2 & Now a days, I seek forgiveness from Allah \\
R3 & Nowadays, I keep myself in Wudu (Ablution) \\
R4 & I read or recite Qu'ran during COVID-19 pandemic \\
R5 & Now a days I am regularly doing Zikr/Tasbeeh (recitation of Quranic \\
& verses/rosary beads) \\
R6 & Now a days I regularly give money/charity (Sadqah) to needy people \\
R7 & I believe that only Allah can protect us and humanity from coronavirus
\end{tabular}

Psychometric properties of religious coping scale.

\begin{tabular}{|c|c|c|c|c|c|c|c|c|c|c|}
\hline & M & SD & R1 & R2 & R3 & R4 & R5 & R6 & R7 & $\begin{array}{l}\text { Corrected Item- } \\
\text { Total Correla- } \\
\text { tion }\end{array}$ \\
\hline R1 & 1.53 & 0.847 & 1 & $0.74^{* *}$ & $0.60^{* *}$ & $0.62^{* *}$ & $0.50^{* *}$ & $0.46^{* *}$ & $0.47^{* *}$ & 0.729 \\
\hline R2 & 1.50 & 0.859 & & 1 & $0.67^{* *}$ & $0.65^{* *}$ & $0.51^{* *}$ & $0.48^{* *}$ & $0.42^{* *}$ & 0.751 \\
\hline R3 & 1.62 & 0.922 & & & 1 & $0.64^{* *}$ & $0.52^{* *}$ & $0.52^{* *}$ & $0.53^{* *}$ & 0.751 \\
\hline R4 & 1.58 & 0.910 & & & & 1 & $0.64^{* *}$ & $0.49^{* *}$ & $0.40^{* *}$ & 0.739 \\
\hline R5 & 1.41 & 0.845 & & & & & 1 & $0.59^{* *}$ & $0.42^{* *}$ & 0.682 \\
\hline R6 & 1.55 & 0.888 & & & & & & 1 & $0.43^{* *}$ & 0.624 \\
\hline R7 & 1.44 & 0.842 & & & & & & & 1 & 0.561 \\
\hline \multicolumn{10}{|c|}{ Cronbach's alpha ó } & 0.893 \\
\hline$\overline{\mathrm{Com}}$ & osite $\mathrm{R}$ & liabilit & & & & & & & & 0.888 \\
\hline
\end{tabular}




\begin{tabular}{clllllllll}
\hline M & SD & R1 & R2 & R3 & R4 & R5 & R6 & R7 & $\begin{array}{l}\text { Corrected Item- } \\
\text { Total Correla- } \\
\text { tion }\end{array}$ \\
\hline Average Variance Extracted (AVE) & & & & & & & & & \\
\hline
\end{tabular}

Funding The authors did not receive any funding to conduct this study.

\section{Compliance with Ethical Standards}

Conflict of interest The authors do not have any conflicts of interest.

Informed consent The authors took informed consent from the respondents participating in the study.

\section{References}

Abdulkareem, S. A., Augustijn, E. W., Filatova, T., Musial, K., \& Mustafa, Y. T. (2020). Risk perception and behavioral change during epidemics: Comparing models of individual and collective learning. PLoS ONE 15(1), e0226483. https://doi.org/10.1371/journal.pone.0226483

Abramowitz, J. S., Deacon, B. J., \& Valentiner, D. P. (2007). The Short Health Anxiety Inventory: Psychometric properties and construct validity in a non-clinical sample. Cognitive Therapy and Research, 31(6), 871-883.

Afridi, M. I. (2008). Mental health: Priorities in Pakistan JPMA. The Journal of the Pakistan Medical Association, 58(5), 225-226.

Ahorsu, D. K., Lin, C. Y., Imani, V., Saffari, M., Griffiths, M. D., \& Pakpour, A. H. (2020). The fear of COVID-19 scale: Development and initial validation. International Journal of Mental Health and Addiction, 8(1), 25-34.

Ali, T. M., \& Gul, S. (2018). Community Mental Health Services in Pakistan: Review Study From Muslim World 2000-2015. Psychology, Community \& Health, 7(1), 57-71.

Asmundson, G. J., \& Taylor, S. (2020). How health anxiety influences responses to viral outbreaks like COVID-19: What all decision-makers, health authorities and health care professionals need to know. Journal of Anxiety Disorders, 71, 102211.

Balaratnasingam, S., \& Janca, A. (2006). Mass hysteria revisited. Current Opinion in Psychiatry, 19(2), $171-174$.

Bashir, A. (2018). The state of mental health care in Pakistan. The Lancet Psychiatry, 5(6), 471.

Blakey, S. M., \& Abramowitz, J. S. (2017). Psychological predictors of health anxiety in response to the Zika virus. Journal of Clinical Psychology in Medical Settings, 24(3-4), 270-278.

Campbell, H. (2004). Challenges created by online religious networks. Journal of Media and Religion, 3(2), 81-99.

Chirico, F., \& Nucera, G. (2020). An Italian experience of spirituality from the Coronavirus pandemic. Journal of Religion and Health. 59(5), 2193-2195 https://doi.org/10.1007/s 10943-020-01036-1

Clark, J. (2003). Fear of SARS thwarts medical education in Toronto. BMJ British Medical Journal, $326(7393), 784$.

Fitzpatrick, K. M., Harris, C., \& Drawve, G. (2020). Fear of COVID-19 and the mental health consequences in America. Psychological Trauma: Theory, Research, Practice and Policy, 12(S1), S17S21. https://doi.org/10.1037/tra0000924

Gall, T. L. (2000). Integrating religious resources within a general model of stress and coping: Long-term adjustment to breast cancer. Journal of Religion and Health, 39(2), 167-182.

Gesser-Edelsburg, A., \& Shir-Raz, Y. (2017). Science vs fear: the Ebola quarantine debate as a case study that reveals how the public perceives risk. Journal of Risk Research, 20(5), 611-633. 
Hart, C. W. (2020). Spiritual Lessons From the Coronavirus Pandemic. Journal of Religion and Health, 59, 623-624. https://doi.org/10.1007/s10943-020-01011-w

Hart, C. W., \& Koenig, H. G. (2020). Religion and Health during the COVID-19 Pandemic. Journal of Religion and Health, 59, 1141-1143. https://doi.org/10.1007/s10943-020-01042-3

Hassan, R. (1987). Religion, society and the state in Pakistan: Pirs and politics. Asian Survey, 27(5), $552-565$.

Hong, B. A., \& Handal, P. J. (2020). Science, Religion, Government and SARS-CoV-2: A Time for Synergy. Journal of Religion and Health. https://doi.org/10.1007/s10943-020-01047-y

Huang, L., Xu, F., \& Liu, H. (2020). Emotional responses and coping strategies of nurses and nursing college students during COVID-19 outbreak. MedRxiv, 52, 18.

James, P. B., Wardle, J., Steel, A., \& Adams, J. (2019). Post-Ebola psychosocial experiences and coping mechanisms among Ebola survivors: a systematic review. Tropical Medicine \& International Health, 24(6), 671-691.

Javaid, D. U. (2011). Genesis and effects of religious extremism in Pakistan. International Journal of Business and Social Science, 2(7), 282-288.

Ji, D., Ji, Y. J., Duan, X. Z., Li, W. G., Sun, Z. Q., Song, X. A., \& Chen, G. F. (2017). Prevalence of psychological symptoms among Ebola survivors and healthcare workers during the 2014-2015 Ebola outbreak in Sierra Leone: a cross-sectional study. Oncotarget, 8(8), 12784.

Koenig, H. G., \& Büssing, A. (2010). The Duke University Religion Index (DUREL): a five-item measure for use in epidemological studies. Religions, 1(1), 78-85.

Koenig, H. G., Wang, Z., Al Zaben, F., \& Adi, A. (2015). Belief into Action Scale: A comprehensive and sensitive measure of religious involvement. Religions, 6(3), 1006-1016.

Lee, S. A. (2020). Coronavirus Anxiety Scale: A brief mental health screener for COVID-19 related anxiety. Death Studies, 8, 1-9.

Levin, J. (2009). How faith heals: A theoretical model. Explore, 5(2), 77-96.

Levin, J. (2020). The Faith Community and the SARS-CoV-2 Outbreak: Part of the Problem or Part of the Solution? Journal of Religion and Health. https://doi.org/10.1007/s10943-020-01048-X

Lima, C. K. T., de Medeiros Carvalho, P. M., Lima, I. D. A. S., de Oliveira Nunes, J. V. A., Saraiva, J. S., de Souza, R. I., \& Neto, M. L. R. (2020). The emotional impact of Coronavirus 2019-nCoV (new Coronavirus disease). Psychiatry research, 76, 112915.

Mahmood, Q. K., Jafree, S. R., Jalil, A., Nadir, S. M. H., \& Fischer, F. (2021). Anxiety amongst physicians during COVID-19: cross-sectional study in Pakistan. BMC Public Health, 21(1), 1-10.

Mahmood, Q. K., Jafree, S. R., \& Qureshi, W. A. (2020). The Psychometric Validation of FCV19S in Urdu and Socio-Demographic Association with Fear in the People of the Khyber Pakhtunkhwa (KPK) Province in Pakistan. International Journal of Mental Health Addiction. https://doi. org/10.1007/s11469-020-00371-4

Mukhtar, M. S. (2020). Mental health and psychosocial aspects of coronavirus outbreak in Pakistan: psychological intervention for public mental health crisis. Asian Journal of Psychiatry. https://doi. org/10.1016/j.ajp.2020.102069

Neuberg, S. L., Warner, C. M., Mistler, S. A., Berlin, A., Hill, E. D., Johnson, J. D., \& Schober, J. (2014). Religion and intergroup conflict: Findings from the global group relations project. Psychological Science, 25(1), 198-206.

Nicomedes, C. J. C., \& Avila, R. M. A. (2020). An analysis on the panic during COVID-19 pandemic through an online form. Journal of Affective Disorders, 276, 14-22.

Ornell, F., Schuch, J. B., Sordi, A. O., \& Kessler, F. H. P. (2020). "Pandemic fear" and COVID-19: mental health burden and strategies. Brazilian Journal of Psychiatry, 42(3), 232-235.

Paloutzian, R. F., \& Park, C. L. (Eds.). (2014). Handbook of the psychology of religion and spirituality. Guilford Publications.

Person, B., Sy, F., Holton, K., Govert, B., \& Liang, A. (2004). Fear and Stigma: The Epidemic within the SARS Outbreak. Emerging Infectious Diseases, 10(2), 358-363.

Peteet, J. R. (2020). COVID-19 Anxiety. Journal of Religion and Health, 59, 2203-2204. https://doi. org/10.1007/s10943-020-01041-4

Rizvi Jafree, S., \& Burhan, S. K. (2020). Health challenges of mothers with special needs children in Pakistan and the importance of integrating health social workers. Social Work in Health Care, 59(6), 408-429.

Rizvi Jafree, S., \& Naqi, S. A. (2020). Significant other family members and their experiences of COVID19 in Pakistan: A qualitative study with implications for social policy. Stigma and Health, 5(4), 380-389. 
Ruland, E. C., Dinca, I., Curtis, V., Barry, M. M., Ekdahl, K., \& Timen, A. (2015). Learning from each other: where health promotion meets infectious diseases. Eurohealth Incorporating Euro Observer, 21(1), 13-16.

Saeed, U., Sherdil, K., Ashraf, U., Younas, I., Butt, H. J., \& Ahmad, S. R. (2021). Identification of potential lockdown areas during COVID-19 transmission in Punjab, Pakistan. Public Health, 190, 42-51.

Safari, M., Pakpour, A. H., Mortazavi, S. F., \& Koenig, H. G. (2017). Psychometric characteristics of the Muslim Religiosity Scale in Iranian patients with cancer. Palliative and Supportive Care, 14(6), 612-620.

Salkovskis, P. M., \& Rimes, K. A., \& Warwick, H. M. C. (2002). The Health Anxiety Inventory: Development and validation of scales for the measurement of health anxiety and hypochondriasis. Psychological Medicine, 32(5), 843-853.

Salman, M., Asif, N., Mustafa, Z. U., Khan, T. M., Shehzadi, N., Hussain, K., \& Khan, M. T. (2020). Psychological impact of COVID-19 on Pakistani university students and how they are coping. MedRxiv, 87, 90.

Shafiq, S. (2020). Perceptions of Pakistani community towards their mental health problems: A systematic review. Global Psychiatry, 3(1), 1-23.

Shah, I., Khalily, M. T., Ahmad, I., \& Hallahan, B. (2019). Impact of conventional beliefs and social stigma on attitude towards access to mental health Services in Pakistan. Community Mental Health Journal, 55(3), 527-533.

Sohail, M. M. (2018). Belief in God's help during hepatitis C: A qualitative study on Muslim patients in Pakistan. Journal of Religion and Health, 21, 1-18.

Sohail, M. M., Mahmood, Q. K., Sher, F., Saud, M., \& Mas'udah S. \& Ida R. . (2019). Coping Through Religiosity, Spirituality and Social Support Among Muslim Chronic Hepatitis Patients. Journal of Religion and Health, 23, 1-15.

Tan, X., Li, S., Wang, C., Chen, X., \& Wu, X. (2004). Severe acute respiratory syndrome epidemic and change of people's health behavior in China. Health Education Research, 19(5), 576-580.

Tix, A. P., \& Frazier, P. A. (1998). The use of religious coping during stressful life events: Main effects, moderation and mediation. Journal of Consulting and Clinical Psychology, 66(2), 411-422.

Torales, J., O’Higgins, M., Castaldelli-Maia, J. M., \& Ventriglio, A. (2020). The outbreak of COVID-19 coronavirus and its impact on global mental health. International Journal of Social Psychiatry, 12, 0020764020915212.

VanderWeele, T. J. (2020). Love of Neighbor During a Pandemic: Navigating the Competing Goods of Religious Gatherings and Physical Health. Journal of Religion and Health. 59, 2196-2202. https:// doi.org/10.1007/s10943-020-01031-6

Wadoum, R. G., Samin, A., Mafopa, N. G., Giovanetti, M., Russo, G., Turay, P., \& Akpablie, J. (2017). Mobile health clinic for the medical management of clinical sequelae experienced by survivors of the 2013-2016 Ebola virus disease outbreak in Sierra Leone, West Africa. European Journal of Clinical Microbiology \& Infectious Diseases, 36(11), 2193-2200.

WHO (2020a). Health Emergency Dashboard. Accessed on July 03, 2020 from https://covid19.who. int/gclid=EAIaIQobChMIy9GLsqiw6gIV19eyCh22iQ4gEAAYASAAEgK_hPD_BwE.

World Health Organization. (2020b). Mental health and psychosocial considerations during the COVID19 outbreak, 18 March 2020 (No. WHO/2019-nCoV/MentalHealth/2020.1). World Health Organization.

Worldometer (2020). Pakistan Population Retrieved from https://www.worldometers.info/world-popul ation/pakistan-population/.

Wortmann, J. H., \& Park, C. L. (2008). Religion and spirituality in adjustment following bereavement: An integrative review. Death Studies, 32(8), 703-736.

Xiang, Y. T., Yang, Y., Li, W., Zhang, L., Zhang, Q., Cheung, T., \& Ng, C. H. (2020). Timely mental health care for the 2019 novel coronavirus outbreak is urgently needed. The Lancet Psychiatry, 7(3), 228-229.

Yip, P. S., Cheung, Y. T., Chau, P. H., \& Law, Y. W. (2010). The impact of epidemic outbreak: the case of severe acute respiratory syndrome (SARS) and suicide among older adults in Hong Kong. Crisis: The Journal of Crisis Intervention and Suicide Prevention. 31(2); 86-92.

Zamanian, H., Eftekhar-Ardebili, H., Eftekhar-Ardebili, M., Shojaeizadeh, D., Nedjat, S., Taheri-Kharameh, Z., \& Daryaafzoon, M. (2015). Religious coping and quality of life in women with breast cancer. Asian Pacific Journal of Cancer Prevention, 16(17), 7721-7725.

Zhao, S., Wu, J., \& Ben-Arieh, D. (2015). Modeling infection spread and behavioral change using spatial games. Health Systems, 4(1), 41-53. 
Zylke, J. W., \& Bauchner, H. (2020). Mortality and morbidity: the measure of a pandemic. JAMA, 324(5), $458-459$.

Publisher's Note Springer Nature remains neutral with regard to jurisdictional claims in published maps and institutional affiliations. 